\title{
Spisanie Kino/Kino Magazine and its role in reflecting and developing Bulgarian film culture
}

\author{
Maya Nedyalkova
}

The only dedicated scholarly and professional film journal currently in Bulgaria - Spisanie Kino/Kino Magazine - provides regular tribune for voicing the concerns and recommendations of the small but active local film guild as well as showcasing the latest academic research, criticism and news. Since its creation, Kino Magazine has played an important part in debates concerning the protection and development of local film and culture. It is a progressive publication, utilising social media and helping host multiple events to expand its following. Kino Magazine actively aims to engage both professionals and cinephiles by paying consistent attention to international film events, new world cinema and famous film auteurs, in addition to the local film industry. The publication balances between a national and a transnational theoretical scope to ensure that it brings to light not only the importance of preserving Bulgarian cinema but also its links with European and global film.

Launched in 1946 as a biweekly periodical, under the name Kino i foto/Cinema and Photo, Kino Magazine was originally under the jurisdiction of Bulgarsko delo/Bulgarian Deed - a governmental foundation with educational, propaganda and archival purposes, which established a monopoly over film distribution and exhibition in the country (Spasov 2015, 64). Closely linked to the Union of Bulgarian Filmmakers, the publication revealed early on an intention to establish cinema as an integral part of national culture. The emergence of domestic cinema provided an opportunity for selfreflection and comparison with the rest of Europe. In this early period, Kino Magazine formed part of the regular and consistent efforts to enrich cultural life in Bulgaria and, thus, reaffirm the cultural independence and significance of the country. During Communism, Kino Magazine (then known as Kinoizkustvo/Film Art) featured a curious mixture of ideologically charged content together with more neutral texts: film history research, festival reports, theoretical analyses and interviews. For instance, a 1971 issue of the publication started with an excerpt from the report of Bulgarian Communist Party leader Todor Zhivkov on the development of arts, and an analysis of what constitutes mature socialist culture. It then moved on to reviews of recent Bulgarian films The Stolen Train (Vladimir Yanchev 1971) and Four Men in a Boxcar (Atanas Traykov 1970) - both detailing the fight between fascists and communist partisans at the end of the Second World War. To balance out such obviously political propaganda pieces, the issue also featured a morphology of documentary filmmaking, an interview with Spanish experimental and surrealist film auteur Luis Buñuel and the script to what would become one of the most well-known and popular domestic family comedies, With Children at the Seaside (Dimitar Petrov 1972). Despite the obvious emphasis on communist and national values, Kino Magazine acknowledged the context within which Bulgarian film culture existed and evolved. The publication regularly organised film-related discussions and facilitated international film school links (Spasov 2015, 64). Thus, even during Communism, Kino Magazine catered not only to a specialist audience but also to local cinephiles, popular and world cinema enthusiasts.

Decades later, Kino Magazine still strives to protect the balance between the scholarly and popular, the national and international. With the shift to democracy in 1989, the publication had to undergo a number of changes, in order to remain viable and competitive in the new context of open-market economy. Despite its decreased circulation, raised price and reduced staff numbers, Kino Magazine remained focused on fostering local and global film culture. To counteract financial problems and, at the same time, help promote new Bulgarian cinema, the current editor-in-chief Lyudmila Dyakova put in place an innovative plan. Since 2005 each new issue of Kino Magazine features on its front page the poster of a new Bulgarian film, whose creators and/or distributors have paid a symbolic sponsor fee. Further benefactors include local and global distributors, publishers, festivals, production 
companies, postproduction studios, the MEDIA programme as well as a lottery operator, which is also an official patron of the Bulgarian Film Academy (Spasov 2015, 65-66). In the context of openmarket economy and competition, Kino Magazine has diversified its sources of funding, proving resilient and forward-thinking in its quest to ensure financial survival while preserving its cultural mission.

During the transition to democracy, Kino Magazine featured many scholarly and journalistic articles focusing on the state and development of the national film industry as part of the international film market. A 2002 issue of the publication saw film producer and scholar Aleksandar Donev wonder whether the Bulgarian film industry was facing an end or a new beginning, professor of Screen Arts Ingeborg Bratoeva discuss with cautious enthusiasm recent productions and the challenges that they were still facing, and film critic and scholar Aleksandar Grozev hope for unity in professional circles, in order to sustain focus on the strategic development of national cinema. At the same time, film and screenwriting professor Maya Dimitrova compared the films of Bulgarian, eastern and western European filmmakers in an attempt to encourage cross-border appropriation and inspiration, while Polish film and theatre director, producer and screenwriter Krzysztof Zanussi contributed a transcribed lecture on the most recent developments in world cinema. The publication also proves a forum to critical pieces, like script-writer Vladimir Ganev's 2010 open letter to the Bulgarian National Film Centre, addressing the lack of transparency in the distribution of the annual film subsidies. Articles published in Kino Magazine reveal a continued preoccupation with the preservation of Bulgarian film, an emphasis on acknowledging the transnational context of its development and a clear political stance.

In present days, Kino Magazine comes out as a bi-monthly publication, exploring selected legislative, industrial and aesthetic aspects of local and global film as well as highlighting relevant events for film professionals and cinephiles. It regularly features sections on Bulgarian and international productions, reports on film festivals, film awards, book reviews, film analyses, new film scripts and interviews with local and foreign talent. In addition, the publication traces developments in television and digital distribution as well as new approaches to film history. There is a further special section dedicated to outlining and interpreting domestic and European legislation. Since 2013, Kino Magazine has also featured international reviews of exported Bulgarian motion pictures (Spasov 2015, 65-66). In addition, the publication has put special emphasis on engaging with the digital literate generation and inviting direct interaction. Each issue of Kino Magazine features special article 'teasers' on the official Union of Bulgarian Filmmakers webpage. The publication has also branched out into social media, maintaining a modest but active following on platforms like Facebook. Since 2015, it has also co-organised free open-air screenings of Bulgarian films across different neighbourhoods in the capital city Sofia, as part of the Blok Kino project (Списание КИНО / Magazine KINO 2017). Hence, Kino Magazine continues its active contribution to local audience development initiatives.

Kino Magazine has gone through a real transformation since its creation. It started as a national cultural publication with clear ideological purposes, but has since transcended its direct ideological mission by gaining certain financial independence and intellectual freedom during Bulgaria's shift to democracy. Nowadays, Kino Magazine highlights the multi-faceted character of Bulgarian film culture and the transnational context of its development. It welcomes a multitude of perspectives on film offering the opportunity for honest discussion and direct engagement.

\section{References}

“Списание КИНО / Magazine KINO.” 2017. Facebook.Com. https://www.facebook.com/pg/spisa nieKino/. 
Petrov, Dimitar, dir. 1972. With Children at the Seaside. Bulgaria: Boyana Film.

Spasov, Rosen. 2015. “Spisanie 'Kino' naslednikat na 'Kinoizkustvo' sled 1991 g” [“Kino Journal,

Successor to Kinoizkustvo Journal Following 1991"]. Problemi Na Izkustvoto/Art Studies Quarterly 3: 64-66.

Traykov, Atanas, dir. 1970. Four Men in a Boxcar. Bulgaria: Boyana Film.

Yanchev, Vladimi, dir. 1971. The Stolen Train. Bulgaria/Soviet Union: Boyana Film/Maksim Gorki Studio. 